DOI: $\underline{\text { https://doi.org/10.34069/AI/2021.42.06.21 }}$

How to Cite:

Gatseliuk, V., Strelbitska, L., Herasymchuk, O., Pavlyshyn, A., \& Khrystiuk, V. (2021). The influence of religion on the norms of criminal law and process: an international-comparative study. Amazonia Investiga, 10(42), 226-235. https://doi.org/10.34069/AI/2021.42.06.21

\title{
The influence of religion on the norms of criminal law and process: an international-comparative study
}

\author{
Вплив релігії на норми кримінального права та процесу: \\ міжнародне компаративістське дослідження
}

Received: June 2, 2021
Accepted: July 12, 2021

\begin{abstract}
Criminal law and process play a significant role in regulating public relations. It is expedient to study it in terms of the influence of religion in different legal systems, as religious norms are the broader regulators of public life. The study of the religious aspect of the formation and functioning of criminal law and criminal procedure relations in different countries is an open question that needs further consideration, as well as prospects for the development of legal institutions based on religious influence. The purpose of the research is to analyze and reflect the impact of religion on the rules of criminal law and process in a comparative international context. The subject of the research is religion and criminal law and process as interdependent phenomena, international comparative study of the influence of religion on the formation of criminal law and process. As a result of the study the mutual influence of law and religion was revealed, the influence of religion on the norms of criminal law and process in different countries was analyzed, it was determined that the religious legal system is most permeated by religious norms in comparison with the legal systems of European countries.
\end{abstract}

Анотація

Кримінальне право та процес займають важливе місце у регулюванні суспільних відносин. Доцільним є його вивчення у аспекті впливу релігії у різних правових системах, оскільки релігійні норми є пер ширшими регуляторами суспільного життя. Вивчення релігійного аспекту формування та функціонування кримінально-правових та кримінальнопроцесуальних відносин у різних країнах $\epsilon$ відкритим питанням, що потребує подальшого дослідження, так само як i перспективи розвитку правових інститутів 3 урахуванням релігійного впливу. Метою дослідження $\epsilon$ аналіз та вивчення впливу релігії на норми кримінального права та процесу у порівняльному міжнародному розрізі. Предметом дослідження виступають релігія та кримінальне право та процес як взаємозалежні явища, міжнародне компаративістське вивчення впливу релігії на формування кримінального права та процесу. У результаті проведеного дослідження виявлено взаємний вплив права та релігії, проаналізовано вплив релігії на норми кримінального права та процесу у різних країнах, визначено, що релігійна правова

\footnotetext{
${ }^{93} \mathrm{Ph}$. D., Senior Researcher of the Department of Criminal Law, Criminology and Judiciary of the Institute of State and Law named after V.M. Koretsky NAS of Ukraine, Ukraine.

${ }^{94} \mathrm{Ph}$. D., Senior Lecturer of Departments of state-legal disciplines of National University of Ostroh Academy, Ukraine.

${ }^{95}$ Ph. D., National University Ostroh Academy, Ukraine.

${ }^{96}$ Ph.D., Associate Professor of Department of Criminal Procedure and Criminalistics, Ivan Franko National University of Lviv, Ukraine.

${ }^{97}$ Ph.D. candidate of the Department of Branch Law of Kherson State University, Ukraine.
} 


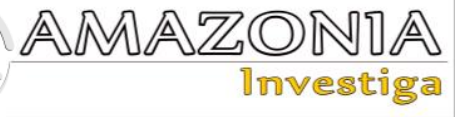

Keywords: religion, religious norms, law, criminal law, criminal procedure.

\section{Introduction}

In the study of the genesis of legal norms and systems, religious norms occupy an important place as the primary source of ordering public life throughout the millennial history of society.

At the stage of the emergence of regulators of public relations, the first were religious norms. As a historically primitive social regulator, religion, by its authority, enshrines certain scales of permissible or undesirable behavior for society, giving them the character of proper. At this point, drew the attention of Sh.L. Montesquieu, pointing out that because certain relationships were considered "unclean" or forbidden, and at the same time necessary (it is a marital relationship), had to turn to religion, in some cases to legitimize them, and in others - to deny (Terzi, \& Zastavska, 2012).

Religious norms are formed on the basis of religious ideas. They are obligatory for subjects who profess a particular religion and have an indirect influence on the behavior of subjects of other religious denominations; the sources of religious norms are sacred texts (for example, the Bible, the Koran, the Torah and others); may be the result of regulatory activities of religious organizations; aimed at regulating the internal and external religious activities of the subjects of religious relations; axiomatic and axiological; form a sacred tradition; are stable.

Religious and legal norms are varieties of social norms and are integral parts of legal systems.

Secular and religious legal families are distinguished according to the degree of influence of religion on legal systems. Unlike secular states, religious states use the prescriptions of religious sources as the basic law, which contains basic provisions for regulating the legal status of the head of state, government, state bodies, citizens, the procedure for making and implementing important decisions, government, compliance with religious principles. Such imperativeness of religious norms is typical, in particular, for the following countries: Saudi Arabia, Qatar, and UAE. система найбільш пронизана релігійними нормами у порівнянні 3 правовими системами європейських країн.

Ключові слова: релігія, релігійні норми, право, кримінальне право, кримінальний процес.

In European countries, the influence of religion on the formation of branches of law is less pronounced, as such countries are secular and have a legislative separation of church and state. It should be noted, that religious norms for the law of secular states are its system-forming element.

The influence of religious norms is most pronounced in the field of criminal and criminal procedure law. Religious sources such as the Bible, the Qur'an, and the Sunnah contain fundamental provisions of a transcendental nature. Thus, according to Bible provisions such as "Thou shalt not kill! Don't steal! Thou shalt not bear false witness against thy neighbor. You shan't covet your neighbor's house" (Exodus. Chapter 20, 13-17), the basis of spiritual relationships is traced, they have become the basis of modern civilization because they have proclaimed the sanctity of human life and the inviolability of private property.

\section{Theoretical Framework or Literature Review}

The modern doctrine of studying the question of the influence of religious norms on the formation of legal systems is based on a large number of works. Among their authors, it is necessary to allocate: Sunegin (2017), Ter-Akopov (2001), Shturmak (2009), Vovk (2009, 2010), Tkachuk (2017), Tsebenko (2019), Zavgorodnya (2017), Mima (2012), Hackeri (2012), Haustova, and Lagutina (2019), Behruz (2012), Nazymko (2015), and Golovchenko (2019).

Research in this area is based on earlier acquisitions of legal doctrine. Among them, it is expedient to pay attention to the views of C.-L. Montesquieu (1955), G. Grotius (1956). Thus, this paper analyzes G. Grotius' view of natural law, namely the unambiguity of its existence, regardless of whether God exists or not. Similarly, in the context of this study, it was necessary to turn to the heritage of the medieval thinker C.-L. Montesquieu, who divided religions and law, giving them a separate sphere of influence. He endowed religion with a certain normativeness for objective reasons. 
Sunegin (2017) concluded that complementary and interdependent normative systems such as law, morality, and religion. In particular, he noted that the value of law as a state social regulator is determined by the nature or degree of its interaction, interaction, and interdependence with morality and religion; legal rules enshrined in law are not perceived as certain restrictions on personal freedom when their content is consistent with internal moral and religious attitudes.

Vovk $(2019,2010)$ devoted several works to the influence of religion on legal norms. In particular, in his work "The relationship between law and religion in the Christian legal tradition: the stage of post-secularization" the author concluded that the stage of the relationship between religion and law in Western civilization is determined by the impossibility of the phenomenon of religiosity; "Rehabilitation" of the religious paradigm in the understanding of the law; increasing interaction of legal and religious systems.

An essential aspect in the context of this study is the analysis of the peculiarities of the legal systems of the world.

This issue is revealed by the following authors:

- Geley, and Rutar (2006) (consider the essence, structure, types, and functions of the political system, revealed the concept of the legal system, detailed political and legal systems of Western Europe, Southeast Asia, Latin America, Central, and Eastern Europe, India, Muslim countries, as well as countries with economies in transition, analyzed the problems, criteria, and factors of effectiveness of these systems);

- Zavgorodnya (2017) studied the general theoretical aspects of the religious legal family, analyzed changes that took place in the religious legal family on the application of legal norms, highlighted such an aspect of the development of the religious legal system as ensuring the development of the individual and the realization of his rights, etc.).

Regarding the direct impact of religious norms on the formation and use of criminal and criminal procedure norms in the literature, there are a small number of works devoted to this topic. This paper analyzes the study of H. Hackeri (2012) "The influence of Islam on criminal law", Vinogradova (2015) "The system of punishment of the Muslim world", Mammadov (2020) "Islamic criminal procedure law: human rights",
Nazymko (2013) "Peculiarities of application of criminal legal means of response to juvenile offenders under the legislation of the Islamic Republic of Pakistan", etc. These studies contain the main provisions on the characteristics of the religious legal system, the functioning of legal institutions, features of criminal and criminal law.

Further study is needed to detail the disclosure of the formation of criminal and criminal procedure law in the religious aspect, the prospects for the development of legal institutions because of religious traditions.

\section{Methodology}

The methodological basis of the study is a set of techniques that allowed to comprehensively study the problematic aspects of the research topic, in particular, the role of historical stages for the formation of law and religion, their interaction, religious aspect in the functioning of legal systems.

The following methods were used in the study:

- The historical method was used to reveal the genesis of the development of legal thought about the role of religion in the regulation of social relations at different historical stages, the views of individual thinkers who expressed views on the interaction of religion and law;

- the method of generalization allowed to draw logical conclusions about the influence of religion on the rules of criminal law and procedure; based on the study of relevant sources in general, the main features of religious and legal norms are highlighted;

- applying the method of analogy, a study of the impact of the Bible on the formation of criminal and criminal procedure law in the legal systems of European countries;

- the method of observation, which consists in allowing the researcher not to resort to continuous research (survey), to obtain generalized data that can legitimately reflect the characteristics of the whole set of objects or phenomena, helped to analyze the features of legal systems and the role of religious norms;

- comparative law method, as the main in comparative studies, was utilized during the formation of a single system of influence of religious dogmas on the law, in general, and criminal and criminal procedure law, in particular. The characteristic features of legal systems, for a better understanding of 


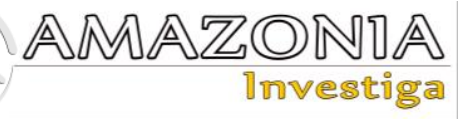

the essence of the factors (that influenced their formation), are also identified;

- the system method made it possible to compile relevant scientific material concerning the interaction of law and religion, to consistently present the results of its analysis;

- the method of analysis let to decompose the central material of the study into its constituent parts, which, in turn, contributed to the disclosure of the topic of the work.

- the method of synthesis was needed during the collection of the necessary information base, which is to highlight the relevant aspects related to the subject;

- method of abstraction. The use of this method allowed to single out the features of legal systems given the influence of religious norms on their formation and development, to determine specific legal norms that were formed under the influence of religion, etc., and;

- the method of analysis of articles, monographs, and other sources allowed a comprehensive approach to the study of the stated topic, to trace the change of opinion on the development of legal norms under the influence of religion, to identify the most appropriate ideas in the context of research.

\section{Results and Discussion}

In a general sense, religion is an objectively existing phenomenon of social existence, a special socio-normative system, norms, and principles based on divine revelation and faith in God or a higher supernatural principle and regulation as the relationship of man with God on the individual, public and state levels. And interpersonal relationships, regardless of their specific manifestation based on higher moral imperatives, the source of which is determined by God himself (Sunegin, 2017).

The history of law traces the close connection between religion and law. Thus, many religious norms had a legal character, regulated some political, state, civil, and other relations.

Medieval thinkers (Ambrose, Blessed Augustine) considered law and religion inextricably linked.

The relationship between law and religion at that time was based on the following positions:

- religion was seen as a means of substantiating the origin and functioning of law and the state;
- the divine legitimation of law and the state conditioned the subordination of the latter and their derivative nature from religion and church, respectively;

- religious means were used to study law. By interpreting the sacred books with logical inferences, religious philosophers sought to prove the dogmas of the faith. The divine nature of law meant the use of the Bible as its source.

During the Renaissance, the understanding of law and religion changed. In particular, there were ideas about their separation. Thus, according to G. Grotius (1956), natural law exists and can exist, even if we assume that God does not exist. Montesquieu (1955) explicitly stated that "what concerns human affairs should not be made the subject of the teachings of divine law, nor should what belongs to divine laws be decided by human law."

Characteristic features of the understanding of law and religion of the XIX century is the rational, free from religious influence nature of law and politics, thinkers of this period produce concepts that somehow return their authors to transcendent categories. A striking example of this understanding of the law is the opinion of a representative of the historical school of law Pukhta, who saw the law as the common will of all members of the legal community, united by a common legal consciousness as a common language, a common religion in one union based on physical and spiritual kinship. The foundation of law is freedom, as a result of which a person becomes a subject of law. In this case, the meaning of human freedom is determined by the existence of the divine will, because the relation of human freedom to the infinite freedom of the almighty God gives its first meaning (Ol, 2005).

In the modern legal literature, there is a pluralism of opinions on the understanding of the essence of law and religion, their relationship, and their role in the regulation of social relations.

Thus, Maltsev (2011) notes that law has always been, is and will be a specific ideology, which not only opens the way to analyze the importance of religion for modern law but also makes it possible to some extent to "reconcile" legal and religious consciousness, without exaggerating the scientific component of the first in line with traditional research. Ter-Akopov (2001) believes that religion is associated with all social institutions, including law, exerting influence on it through the formation of social consciousness and morality. Shturmak's (2009) position on 
determining the ratio of legal and religious norms is characterized by a positivist trend - religious norms end their action where the norms of state law begin to operate.

The influence of religion on law is manifested, in particular, in the influence of the church on public institutions and in the contradictions that arise between the rules of law and religion. Instead, the law, as the central regulator of social relations, can not determine the development of religion but only promotes its existence in various forms through the institution of freedom of conscience and the principle of ideological pluralism, and regulates mechanisms for exercising and exercising religious rights, the order of establishment and functioning of religious organizations (Vovk, 2009), prescriptions that have a traditional or symbolic meaning (enshrinement in the legislation of nonworking days on religious holidays, the obligation to take an oath on the Bible, etc.). Religious norms also introduce the character of humanization into law (prohibition of the death penalty, abolition of cruel and degrading punishments, mitigation of conditions of punishment, expansion of social human rights) (Vovk, 2010).

General aspects of the relationship between law and religion can be expressed in the table by highlighting their properties based on the analysis of the works of such scholars: Tkachuk (2017), Vovk (2010), and Tsebenko (2019) Table 1 .

Table 1.

General aspects of the relationship between law and religion. Information provided by Tkachuk (2017), Vovk (2010), and Tsebenko (2019).

\begin{tabular}{ll}
\hline Religion & Law \\
\hline $\begin{array}{l}\text { Religion is an individual value: the denial of the } \\
\text { existence of transcendent reality leads to the loss of } \\
\text { the influence of religious ideas on human } \\
\begin{array}{l}\text { consciousness and the deprivation of religion of } \\
\text { regulatory qualities. }\end{array}\end{array}$ & $\begin{array}{l}\text { The right is a public value: the right does not lose its } \\
\text { normativeness in case of non-recognition of its value by } \\
\text { an individual. }\end{array}$ \\
$\begin{array}{l}\text { The authoritarian nature of religious consciousness: } \\
\text { the believer always feels the direction of divine } \\
\begin{array}{l}\text { authority. } \\
\text { Religious precepts are aimed at regulating thoughts, } \\
\text { designed to help in individual suffering, hope, } \\
\text { repentance }\end{array}\end{array}$ & $\begin{array}{l}\text { Autonomous nature of legal consciousness: freedom from } \\
\text { external authority. }\end{array}$ \\
$\begin{array}{l}\text { The norms of religion cover only the believing part of } \\
\text { the country }\end{array}$ & The rules of law govern the external side of behavior \\
$\begin{array}{l}\text { Consolidation of rules of conduct in religious sources } \\
\text { The rules of law are national in nature }\end{array}$ & The rules of law are enshrined in law \\
\hline
\end{tabular}

Common features of religion and law are the possibility of violating established norms; the onset of liability for violation of norms (in the case of religion - the court of God, law - the secular court).

The interaction of legal and religious norms in the process of lawmaking is seen in the following:

1) separation and separation of religion and church from the state (for example, Latvia, Portugal, Turkmenistan, Ukraine, Croatia, Yugoslavia, Moldova, and Slovenia);

2) transformation and close relationship of church and religion with the state, when there is an indirect influence on state formation and law-making, proper support of the church of a certain religious current at the legislative level (for example, Argentina, Bolivia, Spain, Italy, and Poland);
3) direct connection of religion and church with the state, official recognition and consolidation of the status of the state religion (for example, Greece, Great Britain, Denmark, Bulgaria, Georgia, and Lithuania);

4) the legal status of religion, church, religious organizations, institutions, and communities is not defined (for example, Hungary, Venezuela, Bosnia and Herzegovina);

5) a ban on the officiality or dominance of any religion in the country (for example, Albania, Slovenia, Estonia);

6) the secular nature of the state (for example, Turkey, France) (Mima, 2012).

A separate type of interaction between legal and religious norms can be distinguished by analyzing the religious legal family, in particular, where Muslim law operates. 


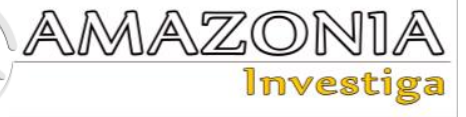

Countries belonging to the Muslim type of society are mainly located in the Middle East, North Africa, and South Asia (Pakistan) (Geley, \& Rutar, 2006).

The right system, where Muslim law prevails, has the following features:

- dogmatism, which is seen in the immutability of religious and legal precepts;

- conservatism, for example, in the field of family relations and protection of traditional values;

- use along with religious legal texts and normative legal acts of international legislation. For example, in 1981, Muslim states adopted the Universal Islamic Declaration of Human Rights, in 1990 the Cairo Declaration on Human Rights in Islam was adopted, in 1994, seven Arab League states agreed to the Arab Charter of Human Rights, in 2012, the heads of the Association of Southeast States. Asia has adopted the Declaration of Human Rights (Zavgorodnya, 2017).

The influence of religion on the norms of Muslim criminal law can be described as follows. First, all the actions and thoughts of man are considered the will of Allah, but man independently chooses specific options for their behavior and is responsible for it. As a result, any serious action is considered a violation of Muslim prohibitions, the general meaning of which is to protect the five principal values: religion, life, reason, procreation, and property (Haustova, \& Lagutina, 2019). Secondly, the crime is considered a manifestation of disobedience to the will of Allah and is considered not only a legally punishable act but also a sin for which the guilty person is responsible in the afterlife.

The chief source of law in Muslim countries is the Qur'an. In the Qur'an, 30 verses are devoted to criminal law.

The precepts of religious law in criminal law are limited to a few offenses, yet, all other punitive norms must be established by political power within the framework of Islamic principles. Thus, the following groups of blocks of crimes are distinguished (Hackeri,2012; Vinogradova, 2015). Crimes that have a fixed punishment, but they violate the rights not only of individuals (murder and bodily harm). In the case of murder, the offender is punishable by death, the relatives of the murdered have the right to choose the form of punishment for the murderer, including monetary compensation in the amount prescribed by law. In this case, the criminal is released from custody; hudud - crimes that are clearly defined in the Qur'an. Such crimes include theft, robbery in a public place, alcohol consumption, illegal sexual intercourse, and slander of illegal sexual intercourse. Tazir crimes are crimes that are not defined in the Qur'an or Sunnah, and for which the right to determine the composition of the crime and establish punishment in Islamic society is given to the state authorities.

It is also possible to single out the principles contained in the precepts of the Qur'an, which are recognized in the criminal law of Muslim countries. These include (Hackeri, 2012):

- the principle of precedent ("O you who believe, do not consider forbidden those things which the Lord has permitted to you", "And We never punish without sending a messenger before");

- prohibition of the retroactive effect of the law ("And never imposed punishment (on the people), without sending before (to him) a messenger" and "God does not demand from anyone more than what he is capable of", "God forgives the past; however, the one who stumbles again will be punished");

- the principle of equality ("There is no other advantage of an Arab over a non-Arab, except his piety ");

- personal responsibility ("And no one will bear the burden of another");

- proportionality ("However, for those who have committed a crime, the same punishment is prepared (as the evil act itself)", "Punishment for the crime will be the same great evil");

- preventive effect of punishments ("Punishment is an obstacle before the act and intimidation after it");

- the principle of ultimate proof (the integrity of the Islamic criminal process is protected by the fact that the rules of evidence are strict, which ensures that criminal sentences and punishments are executed only in cases of guilt.

Islamic law only allows the submission of evidence, that is considered to have an extraordinary degree of immediate reliability. An essential way of proving is the testimony of witnesses (Shahada alshohud). Witnesses are required to be reasonable, not dumb, not deaf, not blind, adults, and not to be punished for a grave action, and their virtue and sense of honor must be beyond criticism. They may not testify in matters relating to blood relations or if they are interested; the principle of a fair and speedy trial 
(the Prophet himself was commanded to judge fairly, for example: Surat al-Shura: "But say: I believe in the Book sent by God; and I am commanded to judge justly among you").

Pre-trial detention and bail are generally not recognized in Islam. The Qur'an explicitly forbids the use of beatings, torture, or inhuman treatment to obtain a confession, as this violates the dignity of the accused and creates a risk of false confession. The prophet warned that "God will torture on the Day of Atonement those who torture people for life." (Mammadov, 2020).

The right to a fair trial implies the establishment of requirements for a judge (kadi), who must be impeccable in his personal conduct (not to accept bribes or gifts, not to engage in commerce, etc.). Kadi is accountable to Allah in the performance of his duties, and the Holy Qur'an reminds him: "Strong, without rudeness, indulgent, but without weakness; such that a strong and influential man should not expect justice from him, and a weak man should not lose hope of his justice. He must be sober, intelligent ... pious and ... he must not be a tyrant and contemptuous" (Mammadov, 2020). When administering justice, a judge does not refer directly to the Qur'an, but books written by authoritative lawyers, theologians, and containing interpretations of the Qur'an.

In addition, the sectoral legislation of Muslim law consists of rules based on classical Islamic law, as well as borrowed from other legal systems, for example, the Law on Islamic Criminal Punishments of the Islamic Republic of Iran (Legal Center, 2008). The first and second parts of this Law have differences in terms of purely religious norms. This can be defined in Articles 12-17 of this Law, which provide for five types of punishment - hadd, kisas, vira, tazir and deterrent measures. Hudud - standardized punishments provided by Islamic religious law; kisas - a punishment imposed on the perpetrator of crimes against life and health, equivalent to the damage caused; vira (action) - material compensation for damages caused by a crime against life and health; tazir - penalties imposed by a court, the types and amounts of which are not established by Islamic religious law and are determined at the discretion of the judge. Hudd crimes include adultery, theft, unfounded accusations of adultery, alcohol use, an armed attack on public order, same-sex relationships, and prostitution (Behruz, 2012).

On the example of Pakistan, it can be argued about the inclusion of the rules of Muslim tort law in secular law. In 1980, the Law on Liability for Blasphemy came into force, and in 1981, liability was established for failing to fast during Ramadan (imprisonment for up to 3 months and a fine of up to Rs 500) (Nazymko, 2015).

Regarding the influence of religious norms on the norms of criminal law and procedure in European countries, it should be noted the dominance of Christianity in their territories. Christianity is professed by more than $1 / 4$ of humanity, $3 / 5$ of them - Catholics, 1/3 - Protestants, 1/10 Orthodox. Catholicism is widespread in the countries of Southern Europe, as well as in France and Poland. Protestantism is practiced in Finland, Sweden, Norway, Denmark, and Iceland.

Orthodoxy is followed by Greeks, peoples of southern Central Europe, CIS countries (Russians, Ukrainians, Georgians, etc.) (Religious Studies, 2011).

Given the vast majority of states where the Christian religion dominates, the assessment of the impact of its norms on the rules of criminal law and the process should be carried out, taking into account religious sources.

The source of the Christian religion is the Bible. It consists of two parts - the books of the Old and New Testaments.

The Old Testament formulates rules of conduct that have all the hallmarks of legal norms criminal law, civil law, administrative law, and procedure. It is no coincidence that one of the chapters of the Bible was called by the Jews the Torah (law). Old Testament rules established liability for crimes against the person, private property, and religion.

The Bible attaches great importance to the problems of justice. The Bible condemns unjust judges: "But they that hate the accused in the gate, and shun him that speaketh truth, $\mathrm{O}$ ye that make a judgment and cast down righteousness to the earth!" (Amos, 5:7, 10). Biblical precepts establish responsibility for unjust justice (Amos 5:11, 14; Jeremiah 7:5) (Golovchenko, 2019).

In modern legal doctrine, it is possible to find the idea of the Bible as the source of criminal law, which is characterized by a clear procedure for determining the sinfulness (illegality) of the act and the establishment of principles of responsibility (Nazymko, 2013). This opinion is fair, given the following facts:

- In the precepts of the Bible, there is the first written mention of the crime. Thus, the first Book of Moses forbade actions that are 


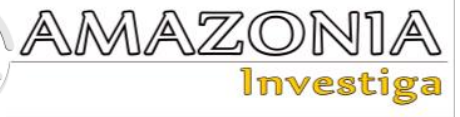

dangerous to man, namely, the consumption of fruit from the "tree of the knowledge of good and evil," for the violation of which accordingly applied a certain punishment death (Genesis, 2:17). In this case, the sinful act in the form of eating the fruit of the "tree of the knowledge of good and evil" is an illegal act, i.e. one of the formal signs of a crime.

The Apostle John gives the following definition of "crime": "Whosoever committeth sin transgresseth also the law" (1 John 3: 4). For committing sin, the law of God contained in Exodus 20, and 21 establishes responsibility for the fact that a person commits a sin by placing it under a "curse" (Deut. 27:26) because in this case, it is a question of crossing limits of Godallowed behavior;

- in such precepts as "And if he touches something unclean, whether the corpse of an unclean beast, or the corpse of unclean cattle, or the corpse of an unclean reptile, but did not know it, then he is unclean and guilty" is the presumption of knowledge of God's laws, in other words, ignorance of which does not absolve from responsibility (the provisions of the Old Testament (Leviticus 5: 2));

- The first mention of imprisonment is found in the Second Book of Chronicles during the imprisonment of the prophet Micah (18:2526);

- the provisions on unjustified sentences are seen as follows: "The case must be heard in the presence of two or three witnesses" (Deuteronomy, 19:15), and emphasizes that only on the basis of the testimony of two or three witnesses should a death row inmate die (Deuteronomy, 17: 6);

- The principle of equality and legitimacy can be found in the following provisions: Judge not the unrighteously poor (Exodus 23: 6), I curse those who misjudge a stranger, an orphan, or a widow (Deuteronomy 27:19), I command you to turn away from unrighteousness, and not to kill the innocent: for I will not justify the wicked (Exodus 23: 7).;

One way or another, the above provisions are contained in the criminal and criminal procedure legislation of many European countries.

It should be noted, that it is characteristic of the legal systems of Western Europe that the law, without being identified with religion, at the same time, takes into account religious rules, giving some of them the quality of legal norms (Table 2).

Table 2.

Provisions containing the influence of religious norms in different countries.

\begin{tabular}{|c|c|}
\hline Country & Provisions containing the influence of religious norms \\
\hline Germany & $\begin{array}{l}\text { According to the German Criminal Code, there is a connection between the formal } \\
\text { definition of a criminal act and the principle of "nullum crimen sine lege", i.e. the } \\
\text { prohibition of an act by criminal law and its punishment; among the signs of the crime } \\
\text { stands out guilt, punishment (Yaroslav the Wise National University of Law, 2016). }\end{array}$ \\
\hline France & $\begin{array}{l}\text { The French Criminal Code preserves the institutions of civilized criminal law, which } \\
\text { were developed in the XVIII century: the principle "no crime - no punishment without its } \\
\text { establishment by law", three-member classification of crimes (crimes, misdemeanors and } \\
\text { violations), responsibility only for outward acts and for the presence of moral guilt } \\
\text { (Legal Services Online, 2021). }\end{array}$ \\
\hline Italy & $\begin{array}{l}\text { The principle of legality as one of the criminal law principles enshrined in the } \\
\text { Constitution of Italy. The provisions of the General Part of the Italian Criminal Code } \\
\text { contain, in particular, rules on crime and punishment (Ignatova, 2021). }\end{array}$ \\
\hline
\end{tabular}

\section{Conclusions}

Given the above material, it is possible to summarize the following:

- law and religion are interrelated phenomena, which is seen in the binding nature of regulations, the onset of punishment for violations of norms, the traditional pursuit of political processes, the formation of legal awareness;
- There are several countries where religion is the central source of regulation of public relations at the official state level. Such states include Iran, Pakistan, Algeria, Morocco, etc. The source of law is the Koran and Sunnah;

- for countries located in Europe, where Christianity is professed, the influence of the provisions of the Bible is typical;

- criminal and criminal procedure legislation has adopted the religious content of norms as 
fundamental principles in the system of regulation of public relations.

Regarding further research, it is necessary to pay attention to the relationship between religion and lawmaking in foreign countries and to consider the role of punishment in religious countries.

\section{Bibliographic references}

Behruz, H. (2012). Religious and secular norms in the legal systems of Islamic states. Comparative Jurisprudence, 3(4), 120-129. Recovered from http://nbuv.gov.ua/UJRN/porpr_2012_3-4_12 Geley, S.D., \& Rutar, S.M. (2006). Political and legal systems of the world. Moscow: Veče. ISBN 5-7838-0441-X. Recovered from https://www.twirpx.com/file/435364/

Golovchenko, V. (2019). Law and the Bible. Legal relations through the prism of Christian doctrine. Legal Bulletin of Ukraine, 10, 14-18. Grotius, G. (1956). On the Law of War and Peace. Moscow: Ladomyr. Recovered from https://www.civisbook.ru/files/File/Groziy_Kn1 .pdf

Hackeri, H. (2012). The influence of Islam on criminal law. Journal of the National University "Ostroh Academy": Law series, 1(5), 1-9. Recovered from http://lj.oa.edu.ua/articles/2012/n1/12hhhnkp.pd $\mathrm{f}$

Haustova, M.G., \& Lagutina, K.O. (2019). The influence of religious traditions on the legal system in the Islamic world. Comparative and Analytical Law, 1, 63-66. Recovered from https://dspace.uzhnu.edu.ua/jspui/bitstream/lib/3 5727/1/\%D0\%92\%D0\%9F\%D0\%9B\%D0\%98 $\% \mathrm{D} 0 \% 92 \% 20 \% \mathrm{D} 0 \% \mathrm{~A} 0 \% \mathrm{D} 0 \% 95 \% \mathrm{D} 0 \% 9 \mathrm{~B} \% \mathrm{D}$ $0 \% 86 \% \mathrm{D} 0 \% 93 \% \mathrm{D} 0 \% 86 \% \mathrm{D} 0 \% 99 \% \mathrm{D} 0 \% 9 \mathrm{D} \%$ D0\%98\%D0\%A5\%20\%D0\%A2\%D0\%A0\%D0 $\% 90 \% \mathrm{D} 0 \% 94 \% \mathrm{D} 0 \% 98 \% \mathrm{D} 0 \% \mathrm{~A} 6 \% \mathrm{D} 0 \% 86 \% \mathrm{D}$ 0\%99.pdf

Ignatova, M.A. (2021). Criminal law of Italy: a textbook for universities. Moscow: Yurayt Publishing House. ISBN 978-5-534-10124-9. Recovered from https://urait.ru/bcode/470178 Legal Center. (2008). Islamic Criminal Penalties Law of the Islamic Republic of Iran. St. Petersburg: Legal Center Press. Recovered from https://iran1979.ru/wp-

content/uploads/2020/09/\%D0\%97\%D0\%B0\%

D0\%BA\%D0\%BE\%D0\%BD-

$\% \mathrm{D} 0 \% \mathrm{BE} \% \mathrm{D} 0 \% \mathrm{~B} 1-$

$\% \mathrm{D} 0 \% \mathrm{~B} 8 \% \mathrm{D} 1 \% 81 \% \mathrm{D} 0 \% \mathrm{BB} \% \mathrm{D} 0 \% \mathrm{~B} 0 \% \mathrm{D} 0 \%$

BC\%D1\%81\%D0\%BA\%D0\%B8\%D1\%85-

$\% \mathrm{D} 1 \% 83 \% \mathrm{D} 0 \% \mathrm{~B} 3 \% \mathrm{D} 0 \% \mathrm{BE} \% \mathrm{D} 0 \% \mathrm{BB} \% \mathrm{D} 0 \%$

BE\%D0\%B2\%D0\%BD\%D1\%8B\%D1\%85-

$\% \mathrm{D} 0 \% \mathrm{BD} \% \mathrm{D} 0 \% \mathrm{~B} 0 \% \mathrm{D} 0 \% \mathrm{BA} \% \mathrm{D} 0 \% \mathrm{~B} 0 \% \mathrm{D} 0$
$\% \mathrm{~B} 7 \% \mathrm{D} 0 \% \mathrm{~B} 0 \% \mathrm{D} 0 \% \mathrm{BD} \% \mathrm{D} 0 \% \mathrm{~B} 8 \% \mathrm{D} 1 \% 8 \mathrm{~F} \%$

D1\%85-

\%D0\%98\%D1\%81\%D0\%BB\%D0\%B0\%D0\% BC\%D1\%81\%D0\%BA\%D0\%BE\%D0\%B9$\% \mathrm{D} 0 \% \mathrm{~A} 0 \% \mathrm{D} 0 \% \mathrm{~B} 5 \% \mathrm{D} 1 \% 81 \% \mathrm{D} 0 \% \mathrm{BF} \% \mathrm{D} 1 \%$ $83 \% \mathrm{D} 0 \% \mathrm{~B} 1 \% \mathrm{D} 0 \% \mathrm{BB} \% \mathrm{D} 0 \% \mathrm{~B} 8 \% \mathrm{D} 0 \% \mathrm{BA} \% \mathrm{D}$ 0\%B8-\%D0\%98\%D1\%80\%D0\%B0\%D0\%BDz-lib.org_.pdf

Legal Services Online. (2021). Criminal law of France and Germany. Recovered from http://yurist-

online.com/ukr/uslugi/yuristam/literatura/krim_ pravo/114.php

Maltsev, G.V. (2011). Social foundations of law. Moscow: Statut. Recovered from https://may.alleng.org/d/jur/jur886.htm

Mammadov, Yu. (2020). Islamic criminal procedure legislation: human rights. Grani, 23(10), 47-57. Recovered from https://grani.org.ua/index.php/journal/article/do wnload/1561/1542

Mima, I.V. (2012). Religious norms as social and law-making factors of society. Almanac of Law, 3, 230-233. Recovered from http://dspace.nbuv.gov.ua/bitstream/handle/123 456789/63912/47-Mima.pdf?sequence $=1$

Montesquieu, C. L. (1955). Selected works. Moscow: Gospolitizdat. Recovered from http://lawlibrary.ru/izdanie1709.html

Nazymko, E.S. (2013). Compliance with Christian values of the regulation of the institution of punishment according to the Criminal Code of Ukraine. European Perspectives, 10, 86-90. Recovered from http://nbuv.gov.ua/UJRN/evpe_2013_10_16

Nazymko, E.S. (2015). Peculiarities of application of criminal-legal means of response to juvenile offenders under the legislation of the Islamic Republic of Pakistan. Scientific herald of the Lviv State University of Internal Affairs, 1, 334-347. Recovered from http://repo.dli.donetsk.ua/jspui/handle/12345678 9/627

Ol, P. A. (2005). Legal understanding: from pluralism to dual unity. St. Petersburg: Legal Center-Press.

Religious Studies. (2011). The population of the world and its confessional structure. Recovered from

https://ru.osvita.ua/vnz/reports/relig/20846/

Shturmak, N.Z. (2009). Peculiarities of religious legal understanding in Ukraine and its role in world religious and legal processes. Jurisprudence: theory and practice, 8, 37-44. Recovered from http://nbuv.gov.ua/UJRN/utp_2009_8_5

Sunegin, S.O. (2017). Law, morality and religion as social regulators: objective and subjective 


\section{AMAZOND用 \\ 1กvestiga}

dimensions. Legal State, 28, 145-163. Recovered from

http://nbuv.gov.ua/UJRN/PrDe_2017_28_20

Ter-Akopov, A. (2001). Christian principles and their development in Russian law. Russian justice, 7, 67-68.

Terzi, O.S., \& Zastavska, L. Yu. (2012). Political and legal views of S. Montesquieu. Nauka. Religion. Society, 4, 110-113. Recovered from http://nbuv.gov.ua/UJRN/Nrs_2012_4_21

Tkachuk, I.D. (2017). Correlation of religion and law as forms of regulation of social relations. Journal of Kyiv University of Law, 4, 47-50. Recovered from http://nbuv.gov.ua/UJRN/Chkup_2017_4_12

Tsebenko, S.B. (2019). Legal and religious norms as regulators of social. Law and Society, 1, 35-39. Recovered from http://pravoisuspilstvo.org.ua/archive/2019/1_2 019/part_1/8.pdf

Vinogradova, S.O. (2015). System of punishments of the countries of the Muslim world. Scientific herald of the Kherson state university. Series: Legal Sciences, 3(2), 61-63. Recovered

http://nbuv.gov.ua/UJRN/Nvkhdu_jur_2015_3 $\% 282 \% 29+17$

Vovk, D. (2010). Correlation of law and religion in the Christian legal tradition: the stage of postsecularization. Bulletin of the Academy of Legal Sciences of Ukraine, 4(63), 58-67. Recovered from

http://dspace.nlu.edu.ua/handle/123456789/617 9

Vovk, D.O. (2009). Law and religion. Kharkiv: Pravo. Recovered from http://library.nlu.edu.ua/POLN_TEXT/MONOG RAFII_2010/Vovk_2009.pdf

Yaroslav the Wise National University of Law. (2016). Methodical recommendations and tasks for practical classes and term papers in the discipline "Comparative Criminal Law". Kharkiv: Yaroslav the Wise National University of Law. Recovered from https://dspace.nlu.edu.ua/bitstream/123456789/1 0323/1/Metod_Rec_150.pdf

Zavgorodnya, Yu. (2017). Religious legal family in modern conditions: general theoretical aspect. Actual problems of domestic jurisprudence, 1(2), 11-13. Recovered from http://nbuv.gov.ua/UJRN/apvu_2017_1\%282\% $29 \_5$ 